\title{
Influence of epibenthos on meiobenthos of the Ceriops tagal mangrove sediment at Gazi Bay, Kenya
}

\author{
J. Schrijvers ${ }^{1, *}$, J. Okondo ${ }^{2}$, M. Steyaert ${ }^{1}$, M. Vincx ${ }^{1}$ \\ ${ }^{1}$ University of Gent, Department of Morphology, Systematics and Ecology, Marine Biology Section, K.L. Ledeganckstraat 35, \\ B-9000 Gent, Belgium \\ ${ }^{2}$ Kenya Marine and Fisheries Research Institute, PO Box 81651, Mombasa, Kenya
}

\begin{abstract}
A cage experiment was used to exclude the epibenthos from the Ceriops tagal mangrove sediment at Gazi Bay, Kenya. This made it possible to study interactions with the meiobenthos (in terms of predation, food competition and food enhancement). The density of the meiobenthic taxa and nematode genera and a broad range of abiotic variables were followed in a depth profile over 1 yr of caging. There was a significant exclusion effect in the upper sediment layer for total meiofauna, nematodes and oligochaetes during the first 2 mo and for copepods during the last 6 mo of caging. The density of the most common predatory and microalgae-feeding nematodes in particular tended to increase in the surface layers as well as the percentage of muddy detritus and pigment concentration. Food competition with the epibenthos seems to be most important in structuring the nematode community. This is suggested by the parallel exclusion effect on muddy detritus, pigments and nematode composition and the lack of evidence for upward nematode migration in the cage during the experiment. The same can be concluded for the oligochaetes, whereas copepod densities are believed to be controlled more by predation. These findings indicate that the meiofauna community of the C. tagal mangrove sediment (consisting of about $95 \%$ nematodes and oligochaetes) is part of a rather isolated, detrital food web with only minor predator-prey interactions with the epibenthos.
\end{abstract}

KEY WORDS: Nematodes - Meiobenthos - Epibenthos - Exclusion experiment - Mangroves - Kenya

\section{INTRODUCTION}

Mangroves in Kenya are becoming increasingly subject to anthropogenic impacts, especially uncontrolled dumping of domestic and industrial wastes (Ruwa \& Polk 1986). The Ceriops tagal mangroves are one of the most extensive and economically important vegetation zones along the coast of Kenya (Kokwaro 1986). A rational management of Kenyan mangroves can only be achieved by analysing structure, function and energy fluxes of the mangrove system and its relation with other ecosystems.

Ecological studies on the meiobenthos in East African mangrove systems are few (Dye \& Furstenberg 1978, Dye 1983a, b, Dye \& Lasiak 1986, Vanhove et al.

•E-mail: jan.schrijvers@rug.ac.be
1992, Vanhove 1993, Schrijvers in press). In the present study, the interactions between the epibenthos (consisting mainly of crabs, gastropods, hermit crabs and - to a lesser extent - of shrimps and demersal fishes) and the meiofauna were examined. This could provide some insight into the role of meiobenthos in Ceriops tagal mangrove soils.

The role of meiobenthos (generally consisting of about $90 \%$ nematodes) in the trophic dynamics of an overall benthic ecosystem has been hypothesized to be 2-fold. (1) The meiobenthos may play an important role in the detrital food web as a self-contained energy sink regulated internally by predation. If this is the case, the meiobenthos depends on, or competes with, the other benthic subsystems (such as the epibenthos) for detrital food (Reise 1979, Heip 1980, Connell 1983, Gee et al. 1985, Olafsson \& Moore 1992, Alkemade et al. 1993, Giere 1993, Walters \& Moriarty 1993). (2) On the other 
hand, several trophic links with the epibenthos have been recognized, mainly in temperate areas. Predation on meiofauna is either selective or non-selective (Bell \& Coull 1978, Reise 1979, Tenore \& Rice 1980, Gee et al. 1985, Marinelli \& Couli 1987, Gee 1989, Hall et al. 1990, McLachlan \& Romer 1990, Castel 1992, Olafsson \& Moore 1992, Giere 1993).

For mangrove sediments as well, the potential influence of the mangrove epibenthos in structuring the meiofauna is broad. One can expect that internally regulated meiofaunal communities are mainly affected by competition with, and food enhancement by, the epibenthos (Bell 1980, Sultan Ali et al. 1983, Dye \& Lasiak 1986, Alongi 1989, Tietjen \& Alongi 1990, Alongi \& Christoffersen 1992), whereas meiofauna that is consumed by this epibenthos would be more predator controlled (Bell 1980, Hoffman et al. 1984, Dittmann 1993). Moreover, the physical disturbance and modification of the mangrove sediment by the epibenthos (mainly through tube digging and feeding activities) may also be of importance (Bright 1977, Bell \& Coull 1978, Alongi \& Tietjen 1980, Bell 1980, Sherman \& Coull 1980, Hoffman et al. 1984, Dye \& Lasiak 1986. Marinelli \& Coull 1987, Alongi 1989, DePatra \& Levin 1989).

\section{MATERIAL AND METHODS}

Study area. The Ceriops tagal mangrove vegetation zone of Gazi Bay, Kenya, is situated $50 \mathrm{~km}$ south of Mombasa $\left(4^{\circ} 25^{\prime} \mathrm{S}\right.$ and $\left.39^{\circ} 50^{\prime} \mathrm{E}\right)$. It has an area of about $0.5 \mathrm{~km}^{2}$. The study site was situated in the nonexploited and patchy $C$. tagal vegetation that borders the west bank of the western creek of the bay. This site is about $2.8 \mathrm{~m}$ above mean low water spring level (intermediate in the tidal range) and is inundated during about $65 \%$ of the high tides (F. J. Slim pers comm.). For a more detailed description of the studied area and station see Schrijvers (in press) and Schrijvers et al. (1995) (Stns C2 and G1, respectively).

Experimental design. All epibenthic and hyperbenthic animals (hereafter called 'epibenthos') (>2 mm) were excluded from the cages, and the influence on the meiobenthic structure was followed through time. In addition to the full cages (C), 2 control treatments were chosen: true blanks (B) and partial cages (P). ' $\mathrm{B}$ ' controlled for temporal natural variation while ' $\mathrm{P}$ ' corrected for possible procedural impacts. Three units were assigned to each treatment. These 9 experimental units were arranged in a randomized block design sensu Hurlbert (1984) to obtain an optimal randomization/interspersion ratio, to reduce the probability of chance segregation of treatments and to yield a more sensitive ANalysis Of VAriance (ANOVA) de- sign. After rerandomization this resulted in:

$$
\begin{array}{lll}
\multicolumn{3}{c}{\text { Bay }} \\
\text { P } & \text { B } & \text { P } \\
\text { C } & \text { C } & \text { B } \\
\text { B } & \text { P } & \text { C } \\
\multicolumn{3}{c}{\text { Land }}
\end{array}
$$

Rerandomization consisted of repeated randomization until no possible gradient could be detected in the design. The units were 1 to $2 \mathrm{~m}$ apart and had a surface of $1 \mathrm{~m}^{2}$ each.

Each blank unit was framed with a rope. The partial cages were identical to the regular cages (Fig. 1), but one side of the upper part was not covered with netting so as to avoid exclusion of epibenthos. The epibenthos in the cages was removed manually within the first $5 \mathrm{~h}$ of the experiment.

Five samples were taken over time: period 1, before caging (6 August 1992); period 2, after $22 \mathrm{~d}$ of caging (28 August 1992); period 3, after 52 d of caging (27 September 1992); period 4, after 139 d of caging (23 December 1992); period 5, after 350 d of caging (30 July 1993).

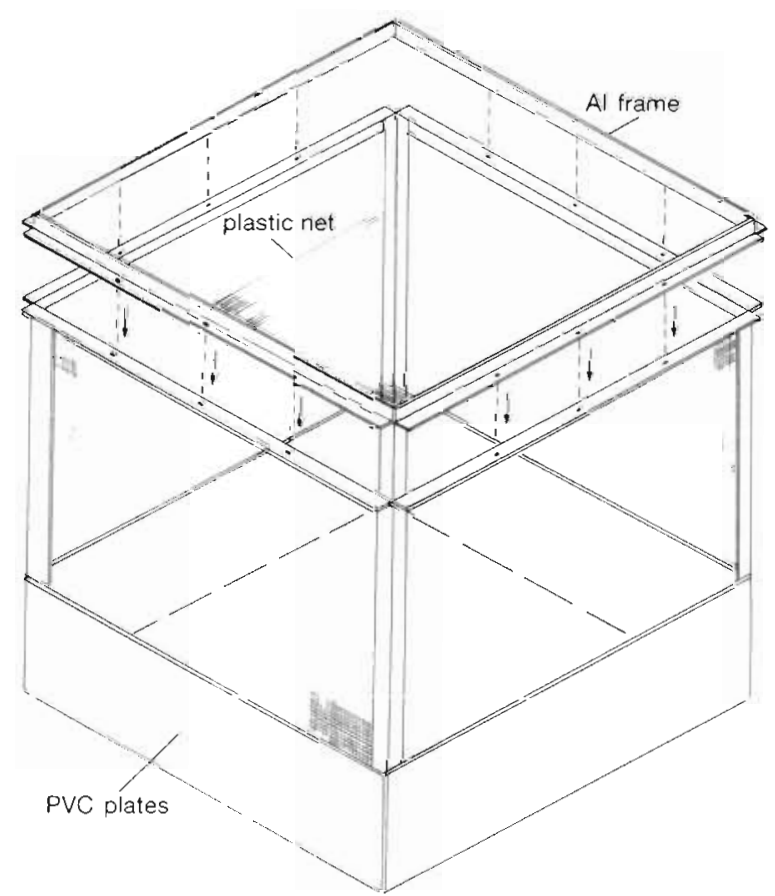

Fig. 1. Model of the cage construction used in the exclusion experiment. It consisted of a lower and upper part. The lower part was composed of four $0.3 \mathrm{~m}$ high perforated PVC plates which were completely buried in the sediment. The upper part was composed of an aluminium frame $(0.7 \mathrm{~m}$ high) that was covered by a plastic net with $2 \mathrm{~mm}$ mesh size. The top was detachable to facilitate sampling. (Drawing by Bruyneel 1995) 
On each occasion, bottom samples were taken at the same coordinates (randomly chosen) of the surface for each unit and within $10 \mathrm{~cm}$ from the edge. Core holes were immediately filled with silicon plugs or sediment bags to avoid influencing the surrounding sediment that was to be sampled later in the experiment (Marinelli \& Coull 1987).

The use of partial cages controlled for possible artefacts (fouling, shading, sedimentation, moisture, litter fall and presence of epibenthos) (Hairston 1990).

Abiotic factors. One $6 \mathrm{~cm}$ diameter core sample was taken in each unit per period. The bottom water in the sample holes was analyzed for bulk values of $\mathrm{pH}$, salinity and dissolved oxygen $\left(\mathrm{DO}_{2}\right)$ with a combined, calibrated electrode with consolidated cover, a refractometer and a Clark type 737 electrode, respectively. Other measurements were performed on vertical slices of the core $(0-2,2-4,4-10,10$-rest $\mathrm{cm})$. Temperature and redox potential were measured in the 3 uppermost slices using a bar thermometer sensitive to $0.01^{\circ} \mathrm{C}$ and a combined Hamilton electrode, respectively. For all slices, the \% of particulate organic matter (POM) and some granulometric variables were determined. After drying at $100^{\circ} \mathrm{C}$, the $\mathrm{POM}$ was quantified via the loss in weight following a $600^{\circ} \mathrm{C}$ combustion for $4 \mathrm{~h}$. A Coulter ${ }^{\otimes}$ LS Particle Size Analyser was used to characterize the granulometry of the sediment. This analysis was done both before and after a $600^{\circ} \mathrm{C}$ combustion. Before analysis, the gravel fraction ( $>850 \mathrm{~mm}$ ) was mechanically separated by sieves.

A $1 \mathrm{~cm}$ diameter core was used to estimate the \% of organic carbon in the slices $0-2,2-4$ and $4-10 \mathrm{~cm}$ with a Carlo Erba NA 1500 series 2 C-analyser. The 2 uppermost slices were analysed for chlorophyll $a$ and fucoxanthin pigment concentration (using a Gilson high-performance liquid chromatography (HPLC) chain according to a slightly modified method of Mantoura \& Llewellyn 1983).

Biotic factors. Samples were obtained by taking 1 handcore $(3.6 \mathrm{~cm}$ diameter $)$ per unit to a depth of $20 \mathrm{~cm}$ and slicing it along a vertical gradient of $0-2,2-4$, $4-10$ and 10 -rest $\mathrm{cm}$. Each slice was preserved in a hot $\left(60^{\circ} \mathrm{C}\right) 4 \%$ formalin solution. Extraction of meiofauna from the sediment (sieve meshes of $38 \mu \mathrm{m}$ and $1 \mathrm{~mm}$ ) was done by centrifugation (2734 $\times g$ for $3 \times 3 \mathrm{~min}$ ) with $\mathrm{MgSO}_{4}$ with a density of 1.28 , a method that allowed for a fast and easy separation of the target fauna from mangrove roots and detritus. The nematodes and other meiofauna taxa were counted. Densities are expressed as numbers of individuals per $10 \mathrm{~cm}^{2}$.

The nematodes of the 3 cage treatment units for periods 1 and 3 were picked out (mean of $3 \times 120$ individuals) and identified to genus level. They were classified in trophic groups according to the commonly used feeding types $1 \mathrm{~A}$ (selective deposit feeders), 2A (epi- stratum feeders), 1B (non-selective deposit feeders) and 2B (omnivores/predators) (Wieser 1953).

Statistical analyses. Non-parametric Spearman rank correlation coefficients were calculated $(p<0.05)$ to determine a relationship between biotic and abiotic variables along the depth gradient and along the horizontal gradient within the upper layer.

An ANOVA was used to test for significant differences of meiofauna densities in different treatments ( $B$, $P$ and $C$ ), periods ( 1 to 5 ) and slices (the 4 mentioned above). A $3 \times 4$ (between groups) $\times 5$ (within subjects) design was constructed, with treatments and slices as groups and periods as subjects repeated over time. Detailed comparison between groups was done by a contrast analysis. Exclusion effects $(E)$ were defined as significant differences between cage and blank-partial cage, while procedural effects (Pr) yielded significant differences between cage-partial cage and blank. The density data were root-root transformed and the \% values of abiotic variables were transformed angularly to meet the ANOVA assumptions (normality, homogeneity of variances and non-correlation between means and variances).

\section{RESULTS}

\section{Spatial distribution patterns}

$$
\text { Depth profile }
$$

The ANOVA for the total slice effect indicated a significant $(p<0.05)$ depth gradient in the sediment for both abiotic and biotic factors. Fig, 2 shows the existence of a prominent gradient from sandy, welloxygenated, warm and pigment-rich surface layers to muddy, less oxygenated, colder and pigment-poor deeper layers.

Most meiofauna taxa (e.g. nematodes, oligochaetes and copepods) had significantly higher densities in the upper layers. In contrast, the halacaroids did not follow this pattern: they were significantly more abundant in slice 4-10 cm (Fig. 2). Other meiofauna taxa did not show a prominent depth pattern.

\section{Horizontal pattern in the upper layer}

To exclude the overriding vertical pattern, the Spearman rank correlation coefficients were calculated for all $0-2 \mathrm{~cm}$ layers (Table 1 ). A clear division could be made between muddy and sandy patches. The former were positively correlated with detritus and pigments, while the latter were characterized by higher temperatures. Copepods, kinorhynchs, oligochaetes and polychaetes 

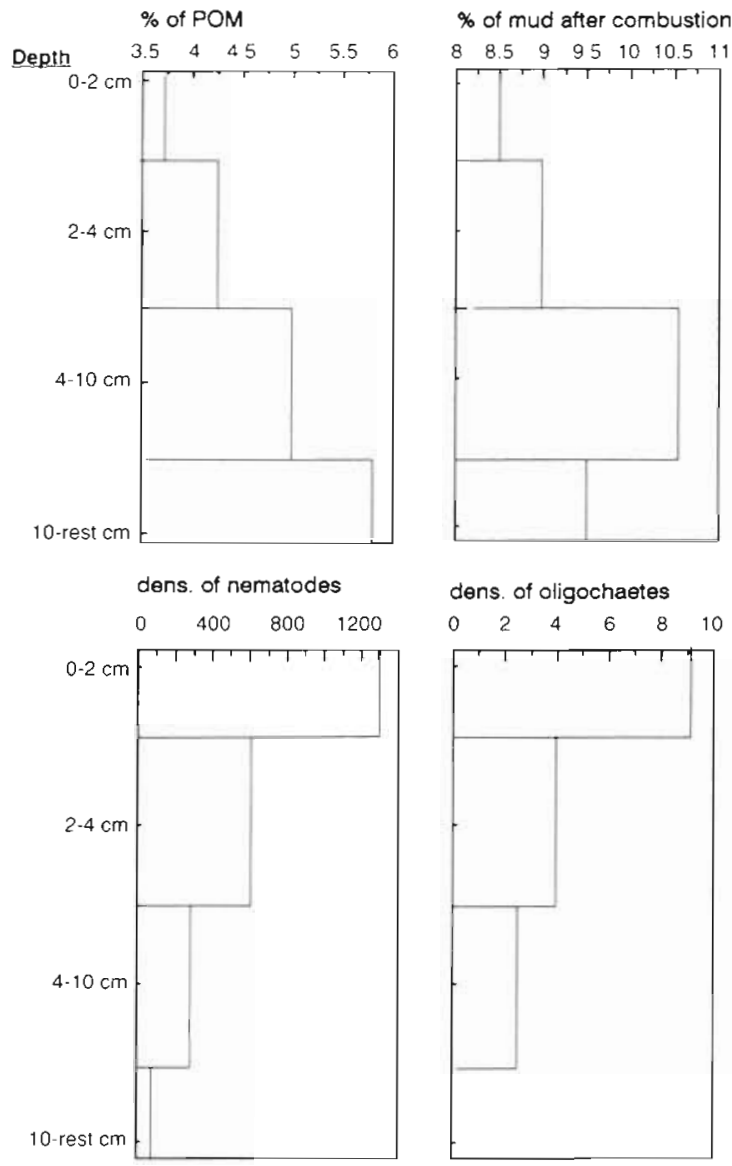
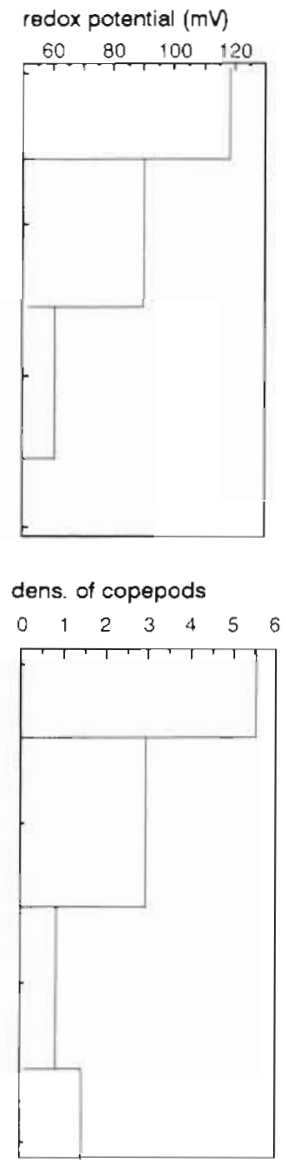

temperature $\left({ }^{\circ} \mathrm{C}\right)$

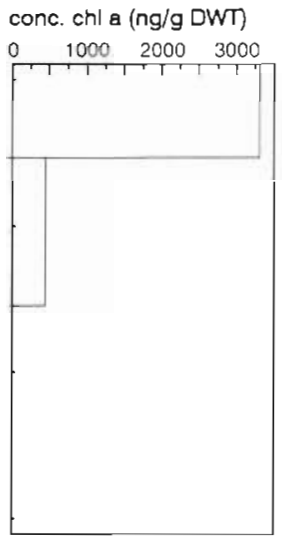

$25.4258262 \quad 26.6 \quad 27$
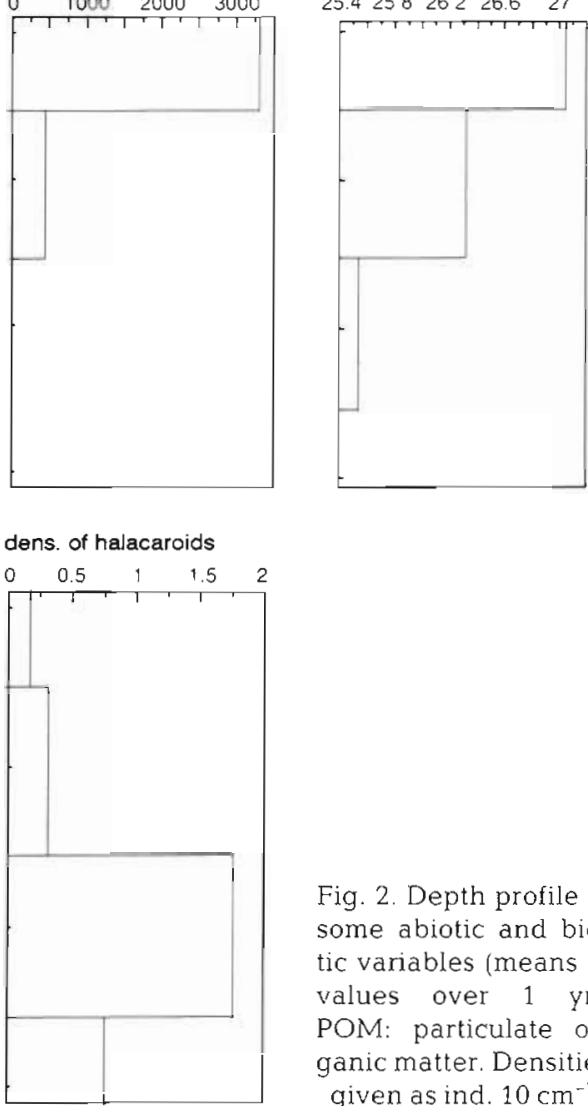

Fig. 2. Depth profile of some abiotic and biotic variables (means of values over $1 \mathrm{yr}$. POM: particulate organic matter. Densities given as ind $10 \mathrm{~cm}^{-2}$ occurred in higher densities in the first habitat. These taxa, together with ostracods, also showed a tendency to avoid high temperatures but preferred high salinities and chlorophyll a concentrations.

\section{Experimental results}

ANOVA allowed us to detect significant differences among treatments within specific periods and vice versa.
The raw data are presented in Figs. $3,4,5,7 \& 10$. Means with standard deviations can be found in Tables 2,3 \& 5 .

Abiotic factors

Exclusion effect. Highly significant exclusion effects $(p<0.01)$ were demonstrated for chlorophyll $a$ and fucoxanthin concentration in the surface layer (Fig. 3, Table 2).

Table 1. Significant positive and negative Spearman rank correlations $(p<0.05)$ for some abiotic and biotic variables. Cope: copepods; Kino: kınorhynchs; Olig: oligochaetes; Poly: polychaetes; Ostr: ostracods; Hala: halacaroids

\begin{tabular}{|c|c|c|c|c|c|c|c|c|c|}
\hline & Cope & Kino & Olig & Poly & Ostr & Hala & Temp & Chl a & POM \\
\hline$\%$ of mud before combustion & + & + & & + & & & - & + & \\
\hline$\%$ of mud after combustion & & & + & + & & & & + & + \\
\hline$\%$ of sand before combustion & & & & - & - & & + & - & - \\
\hline$\%$ of sand after combustion & & & - & - & & & & - & - \\
\hline Salinity (ppt) & + & & & & + & & - & & - \\
\hline Temperature $\left({ }^{\circ} \mathrm{C}\right)$ & - & - & & & - & & & & \\
\hline Chlorophyll a (ng g $\mathrm{g}^{-1}$ dry wt) & + & + & + & & + & & & + & + \\
\hline Fucoxanthin (ng g ${ }^{-1}$ dry wt) & & & & & & - & + & + & \\
\hline$\%$ of POM & & & & & & & & + & + \\
\hline
\end{tabular}




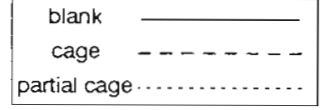

Fig. 3. Fucoxanthin and chlorophyll a concentration (ng $\mathrm{g}^{-1}$ dry $w t)$ in the cage, partial cage and blank: mean values of the 2 upper layers over time. E: significant exclusion effect with $p<0.05$

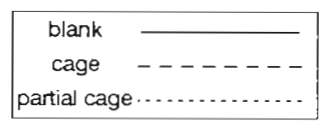

Fig. 4. Mud before combustion $(\%)$ and temperature $\left({ }^{\circ} \mathrm{C}\right)$ in the cage, partial cage and blank: mean values of the 2 upper layers over time. E: significant exclusion effect with $p<0.05$

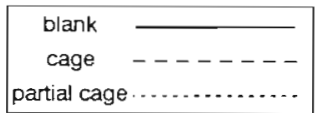

Fig. 5. Mud after combustion $(\%)$ and salinity (ppt) in the $2-4 \mathrm{~cm}$ cage, partial cage and blank: mean values of the 2 upper layers over time. Pr: significant procedural effect with $p<$ 0.05 fucoxanthin concentration (ng/g DWT)
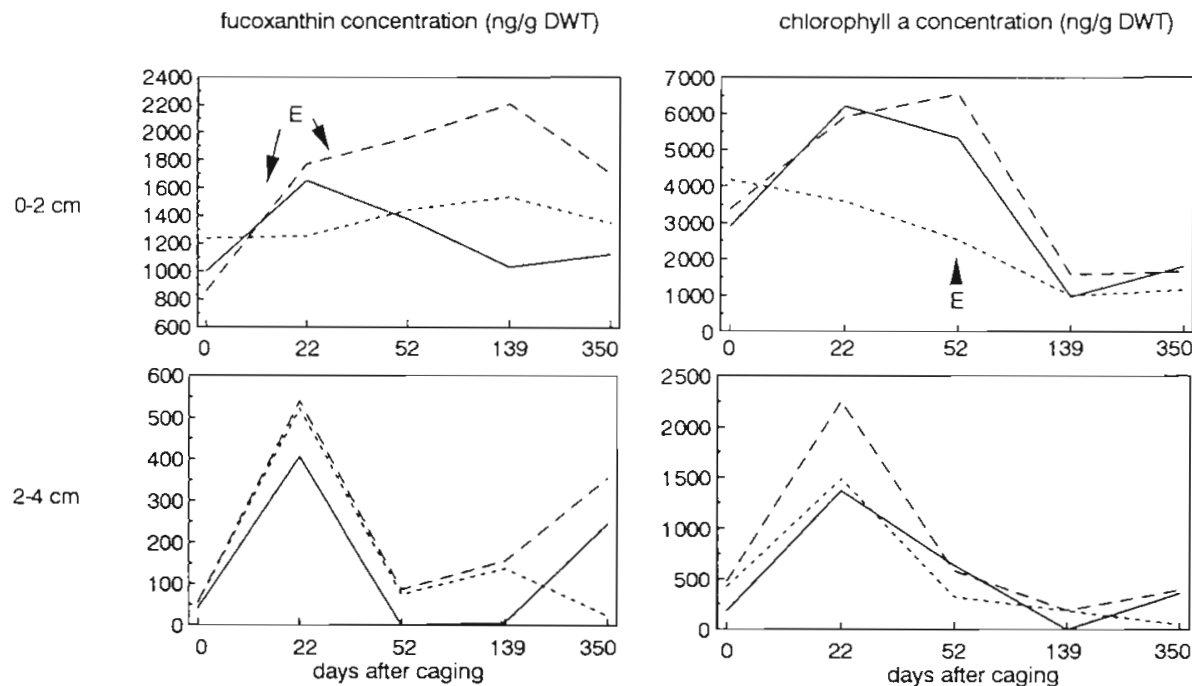

of mud before combustion
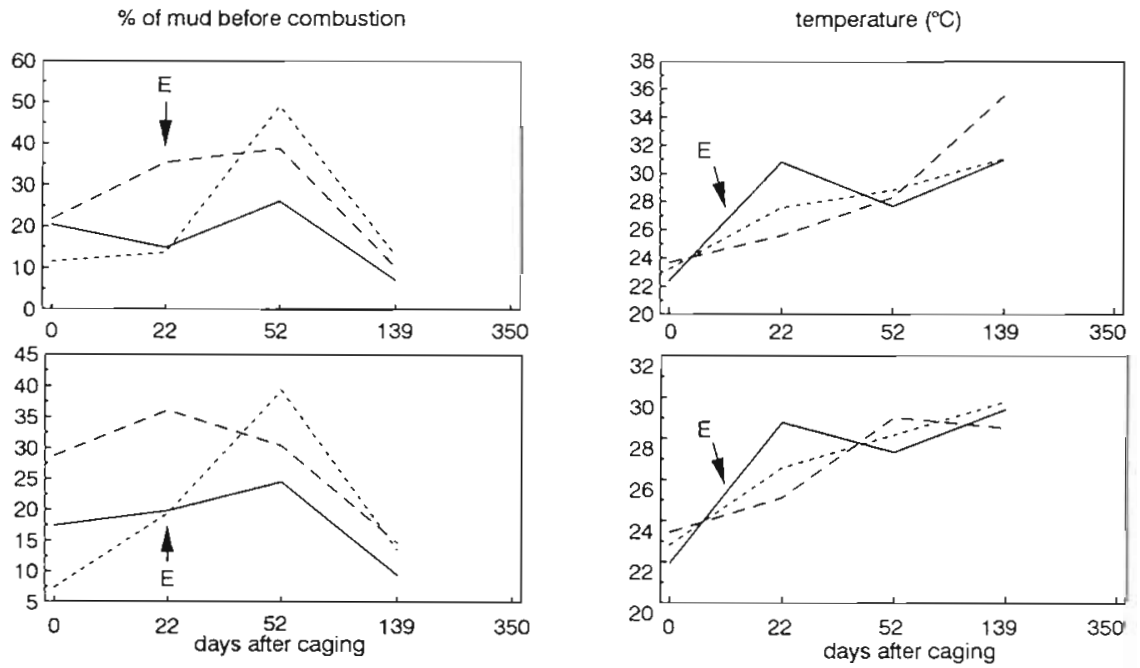

salinity (ppt)
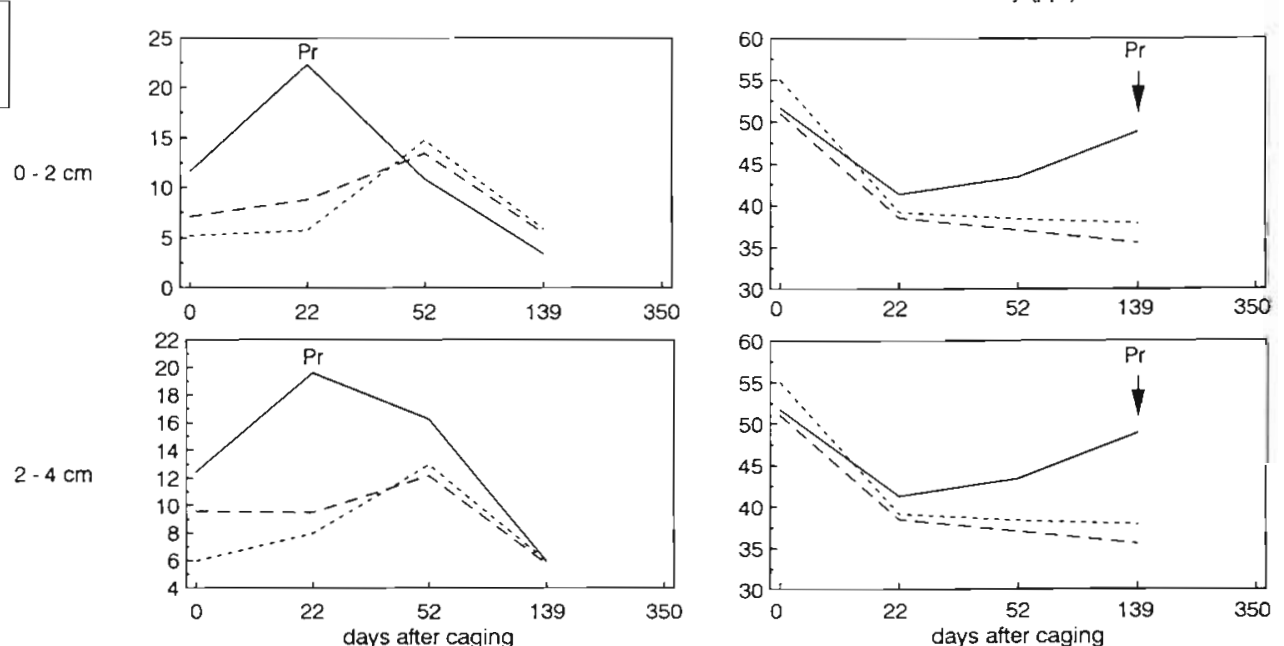
Table 2. Mean and standard deviation values of some abiotic factors of the 2 upper layers in the 3 treatments $(B, C$ and $P$ ) over 5 periods

\begin{tabular}{|c|c|c|c|c|c|c|}
\hline & Treatment & Period 1 & Period 2 & Period 3 & Period 4 & Period 5 \\
\hline $\begin{array}{l}\text { Slice } 0-2 \mathrm{~cm} \\
\text { Chlorophyll } a \text { (ng g }{ }^{-1} \text { dry wt) }\end{array}$ & $\begin{array}{l}B \\
C \\
P\end{array}$ & $\begin{array}{l}2910 \pm 687 \\
3377 \pm 429 \\
4167 \pm 1342\end{array}$ & $\begin{array}{l}6199 \pm 96 \\
5903 \pm 383 \\
3584 \pm 1575\end{array}$ & $\begin{array}{l}5308 \pm 1451 \\
6534 \pm 897 \\
2526 \pm 1864\end{array}$ & $\begin{array}{r}970 \pm 991 \\
1556 \pm 495 \\
982 \pm 570\end{array}$ & $\begin{array}{l}1795 \pm 1365 \\
1642 \pm 573 \\
1147 \pm 446\end{array}$ \\
\hline Fucoxanthin (ng g ${ }^{-1}$ dry wt) & $\begin{array}{l}B \\
C \\
P\end{array}$ & $\begin{aligned} 1002 & \pm 357 \\
861 & \pm 92 \\
1238 & \pm 413\end{aligned}$ & $\begin{array}{l}1649 \pm 182 \\
1771 \pm 115 \\
1254 \pm 341\end{array}$ & $\begin{array}{l}1377 \pm 506 \\
1960 \pm 270 \\
1441 \pm 540\end{array}$ & $\begin{array}{l}1030 \pm 390 \\
2205 \pm 291 \\
1533 \pm 169\end{array}$ & $\begin{array}{l}1125 \pm 517 \\
1703 \pm 754 \\
1349 \pm 224\end{array}$ \\
\hline$\%$ of mud before combustion & $\begin{array}{l}\mathrm{B} \\
\mathrm{C} \\
\mathrm{P}\end{array}$ & $\begin{array}{l}20.49 \pm 13.88 \\
21.66 \pm 7.54 \\
11.51 \pm 11.56\end{array}$ & $\begin{array}{l}14.79 \pm 8.12 \\
35.32 \pm 10.52 \\
13.61 \pm 3.97\end{array}$ & $\begin{array}{l}26.06 \pm 3.1 \\
38.68 \pm 7.18 \\
49.05 \pm 12.89\end{array}$ & $\begin{array}{r}9.01 \pm 0.86 \\
10.20 \pm 3.71 \\
12.99 \pm 2.45\end{array}$ & \\
\hline Temperature $\left({ }^{\circ} \mathrm{C}\right)$ & $\begin{array}{l}B \\
C \\
P\end{array}$ & $\begin{array}{r}22.37 \pm 1.87 \\
23.67 \pm 0.66 \\
23.2 \pm 1.10\end{array}$ & $\begin{array}{l}30.80 \pm 2.57 \\
25.57 \pm 1.54 \\
27.57 \pm 3.24\end{array}$ & $\begin{array}{l}27.67 \pm 0.74 \\
28.33 \pm 0.90 \\
28.83 \pm 2.38\end{array}$ & $\begin{array}{l}30.97 \pm 2.04 \\
29.03 \pm 0.05 \\
31.07 \pm 2.48\end{array}$ & \\
\hline$\%$ of mud after combustion & $\begin{array}{l}\mathrm{B} \\
\mathrm{C} \\
\mathrm{P}\end{array}$ & $\begin{array}{r}11.63 \pm 0.02 \\
7.11 \pm 3.33 \\
5.18 \pm 2.81\end{array}$ & $\begin{array}{r}22.26 \pm 3.48 \\
8.76 \pm 3.94 \\
5.73 \pm 1.13\end{array}$ & $\begin{array}{l}10.84 \pm 5.76 \\
13.43 \pm 3.09 \\
14.73 \pm 2.10\end{array}$ & $\begin{array}{l}3.39 \pm 0.35 \\
5.40 \pm 1.34 \\
5.85 \pm 1.18\end{array}$ & \\
\hline Salinity (ppt) & $\begin{array}{l}\mathrm{B} \\
\mathrm{C} \\
\mathrm{P}\end{array}$ & $\begin{array}{l}51 \pm 3 \\
51 \pm 5 \\
55 \pm 5\end{array}$ & $\begin{array}{l}41 \pm 2 \\
39 \pm 0 \\
39 \pm 3\end{array}$ & $\begin{array}{l}43 \pm 3 \\
37 \pm 1 \\
38 \pm 3\end{array}$ & $\begin{array}{l}49 \pm 3 \\
36 \pm 0 \\
38 \pm 2\end{array}$ & \\
\hline $\begin{array}{l}\text { Slice } 2-4 \text { cm } \\
\text { Chlorophyll a (ng g }{ }^{-1} \text { dry wt) }\end{array}$ & $\begin{array}{l}B \\
C \\
P\end{array}$ & $\begin{array}{r}1826 \pm 157 \\
478 \pm 341 \\
423 \pm 368\end{array}$ & $\begin{array}{l}1369 \pm 0 \\
2249 \pm 3051 \\
1485 \pm 1742\end{array}$ & $\begin{array}{l}633 \pm 451 \\
576 \pm 497 \\
325 \pm 460\end{array}$ & $\begin{aligned} 1 & \pm 2 \\
189 & \pm 225 \\
186 & \pm 264\end{aligned}$ & $\begin{array}{c}353 \pm 499 \\
388 \pm 176 \\
49 \pm 69\end{array}$ \\
\hline Fucoxanthin (ng g ${ }^{-1}$ dry wt) & $\begin{array}{l}B \\
C \\
P\end{array}$ & $\begin{array}{l}41 \pm 57 \\
56 \pm 79 \\
54 \pm 76\end{array}$ & $\begin{array}{l}405 \pm 0 \\
539 \pm 636 \\
522 \pm 738\end{array}$ & $\begin{array}{c}0 \pm 0 \\
87 \pm 123 \\
75 \pm 106\end{array}$ & $\begin{aligned} 6 & \pm 9 \\
156 & \pm 117 \\
137 & \pm 193\end{aligned}$ & $\begin{aligned} 246 & \pm 313 \\
137 & \pm 193 \\
24 & \pm 35\end{aligned}$ \\
\hline$\%$ of mud before combustion & $\begin{array}{l}\mathrm{B} \\
\mathrm{C} \\
\mathrm{P}\end{array}$ & $\begin{array}{r}17.47 \pm 5.03 \\
28.67 \pm 9.13 \\
7.3 \pm 3.68\end{array}$ & $\begin{array}{l}19.79 \pm 5.83 \\
36.09 \pm 8.62 \\
19.37 \pm 3.3\end{array}$ & $\begin{array}{l}24.49 \pm 1.63 \\
30.31 \pm 6.55 \\
39.28 \pm 11.68\end{array}$ & $\begin{array}{r}9.43 \pm 1.91 \\
14.67 \pm 8.71 \\
13.47 \pm 4.62\end{array}$ & \\
\hline Temperature $\left({ }^{\circ} \mathrm{C}\right)$ & $\begin{array}{l}B \\
C \\
P\end{array}$ & $\begin{array}{l}21.93 \pm 1.75 \\
23.43 \pm 0.61 \\
22.83 \pm 1.38\end{array}$ & $\begin{array}{l}28.77 \pm 2.41 \\
25.13 \pm 1.07 \\
26.57 \pm 2.49\end{array}$ & $\begin{array}{l}27.33 \pm 0.62 \\
27.73 \pm 0.54 \\
28.17 \pm 2.00\end{array}$ & $\begin{array}{l}29.43 \pm 0.62 \\
28.50 \pm 0.16 \\
29.80 \pm 1.98\end{array}$ & \\
\hline$\%$ of mud after combustion & $\begin{array}{l}B \\
C \\
P\end{array}$ & $\begin{array}{l}12.40 \pm 3.03 \\
9.61 \pm 3.58 \\
5.96 \pm 2.51\end{array}$ & $\begin{array}{r}19.60 \pm 4.18 \\
9.50 \pm 1.21 \\
7.97 \pm 0.89\end{array}$ & $\begin{array}{l}16.25 \pm 2.89 \\
12.17 \pm 2.49 \\
12.95 \pm 1.25\end{array}$ & $\begin{array}{l}5.94 \pm 1.46 \\
5.75 \pm 1.18 \\
5.93 \pm 0.92\end{array}$ & \\
\hline Salinity (ppt) & $\begin{array}{l}B \\
C \\
P\end{array}$ & $\begin{array}{l}52 \pm 3 \\
51 \pm 5 \\
55 \pm 5\end{array}$ & $\begin{array}{l}41 \pm 2 \\
39 \pm 0 \\
39 \pm 3\end{array}$ & $\begin{array}{l}43 \pm 3 \\
37 \pm 1 \\
38 \pm 3\end{array}$ & $\begin{array}{l}49 \pm 3 \\
36 \pm 0 \\
38 \pm 2\end{array}$ & \\
\hline
\end{tabular}

A significant exclusion effect $(p<0.05)$ on $\%$ of mud before combustion was notable in slices $0-2 \mathrm{~cm}$ and $2-4 \mathrm{~cm}$ (Fig. 4, Table 2). The increase in temperature during the first 22 caging days for slices $0-2 \mathrm{~cm}$ and $2-4 \mathrm{~cm}$ in the cages appeared as an exclusion effect (Fig. 4, Table 2).

Procedural effect. Two variables (Fig. 5, Table 2) underwent a clear cage construction effect.

In contrast with the muddy fraction before combustion, the $\%$ of mud after combustion was influenced by the experimental procedure in the upper slices. The evolution of the \% of muddy detritus is clearly visible in Fig. 6 .

Four months later, the blank salinity was significantly higher than the salinity in both other treatments.
No effect. Clear effects on $\%$ of POM, \% of $\mathrm{C}$, $\mathrm{pH}_{\mathrm{r}}, \mathrm{DO}_{2}$ and other granulometric factors were not detected.

\section{Biotic factors}

Exclusion effect. Exclusion effects were observed for nematode and total meiofauna density in slices $0-2$ and 2-4 cm (Fig. 7. Table 3). It showed an increase of 1.5 to $2 \times$ in the cages as compared to control treatments.

The nematode increase in the surface layer of the cage in period 3 was not accompanied by a clear 
before caging
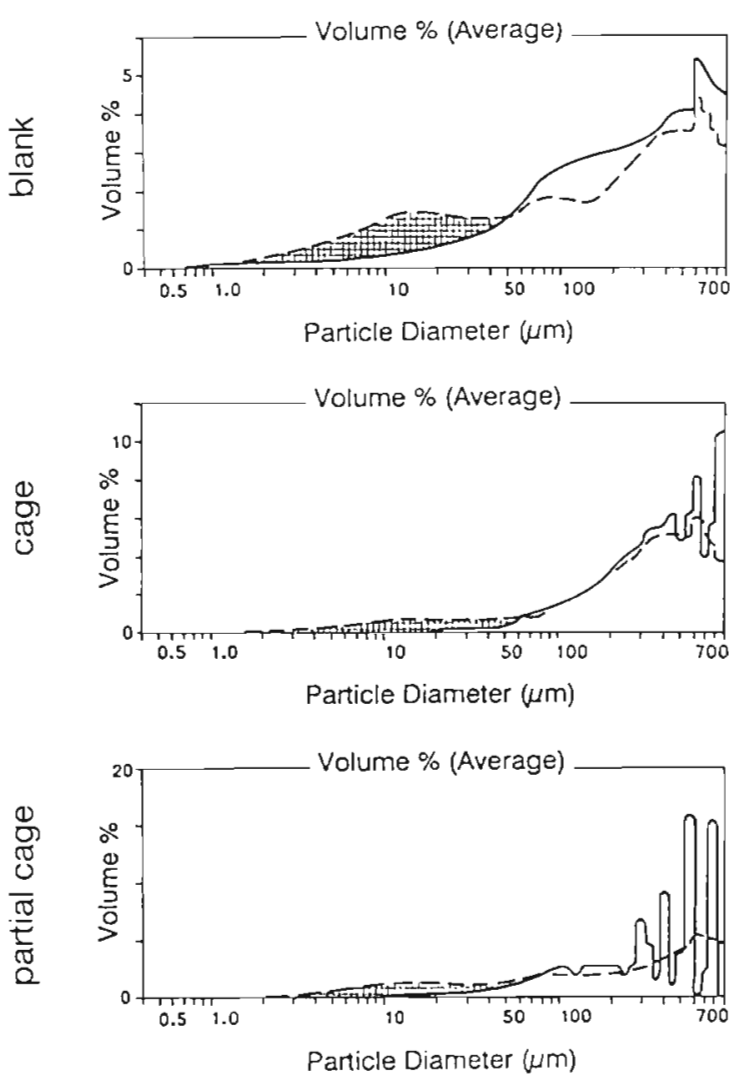

52 days after caging
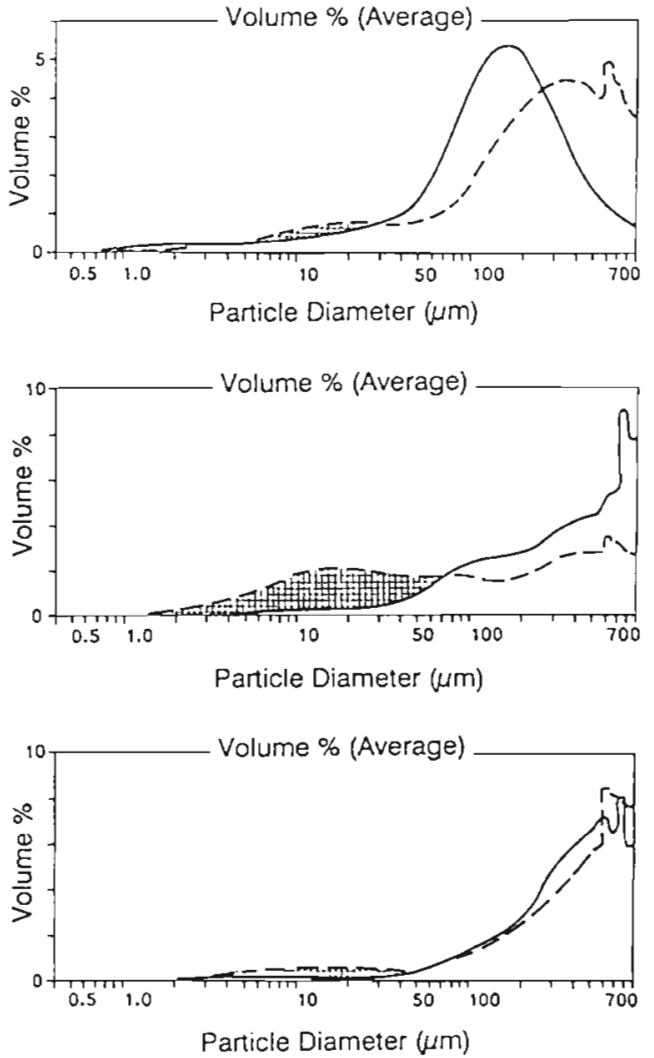

$--1 \%$ of mud before combustion) - ( $\%$ of mud after combustion)
$=\%$ of muddy detritus

Fig. 6. Grain size composition before and after combustion (volume \%) of the surface layer in cage, partial cage and blank sites over 2 periods (with indication of the \% of muddy detritus)

Table 3. Mean and standard deviation values of total meiobenthos and nematode density (ind. $10 \mathrm{~cm}^{-2}$ ) of the 2 upper layers in the 3 treatments ( $B, C$ and $P$ ) over 5 periods

\begin{tabular}{|c|c|c|c|c|c|c|}
\hline & Treatment & Period 1 & Period 2 & Period 3 & Period 4 & Period 5 \\
\hline \multicolumn{7}{|l|}{ Slice $0-2 \mathrm{~cm}$} \\
\hline \multirow[t]{3}{*}{ Total meiobenthos } & $\mathrm{B}$ & $1298 \pm 142$ & $1018 \pm 531$ & $624 \pm 30$ & $700 \pm 206$ & $1476 \pm 305$ \\
\hline & $\mathrm{C}$ & $1542 \pm 142$ & $1865 \pm 278$ & $2120 \pm 156$ & $1255 \pm 584$ & $2676 \pm 415$ \\
\hline & $P$ & $1409 \pm 382$ & $1542 \pm 153$ & $1024 \pm 206$ & $700 \pm 206$ & $2089 \pm 393$ \\
\hline \multirow[t]{3}{*}{ Nematoda } & $\mathrm{B}$ & $713 \pm 39$ & $873 \pm 446$ & $562 \pm 11$ & $627 \pm 228$ & $1451 \pm 319$ \\
\hline & $\mathrm{C}$ & $1182 \pm 204$ & $1663 \pm 219$ & $1972 \pm 154$ & $1235 \pm 497$ & $2620 \pm 351$ \\
\hline & $\mathrm{P}$ & $952 \pm 151$ & $1354 \pm 153$ & $894 \pm 174$ & $1084 \pm 324$ & $2027 \pm 356$ \\
\hline \multicolumn{7}{|l|}{ Slice $2-4 \mathrm{~cm}$} \\
\hline \multirow[t]{3}{*}{ Total meiobenthos } & B & $1195 \pm 312$ & $527 \pm 359$ & $241 \pm 64$ & $420 \pm 229$ & $548 \pm 120$ \\
\hline & $\mathrm{C}$ & $650 \pm 249$ & $582 \pm 135$ & $608 \pm 338$ & $802 \pm 298$ & $849 \pm 313$ \\
\hline & $\mathrm{P}$ & $1010 \pm 295$ & $439 \pm 212$ & $377 \pm 212$ & $759 \pm 357$ & $965 \pm 318$ \\
\hline \multirow[t]{3}{*}{ Nematoda } & $\mathrm{B}$ & $481 \pm 178$ & $458 \pm 309$ & $221 \pm 63$ & $403 \pm 224$ & $544 \pm 117$ \\
\hline & C & $564 \pm 231$ & $554 \pm 44$ & $596 \pm 343$ & $799 \pm 296$ & $845 \pm 313$ \\
\hline & $\mathrm{P}$ & $652 \pm 205$ & $410 \pm 200$ & $359 \pm 211$ & $757 \pm 356$ & $963 \pm 318$ \\
\hline
\end{tabular}



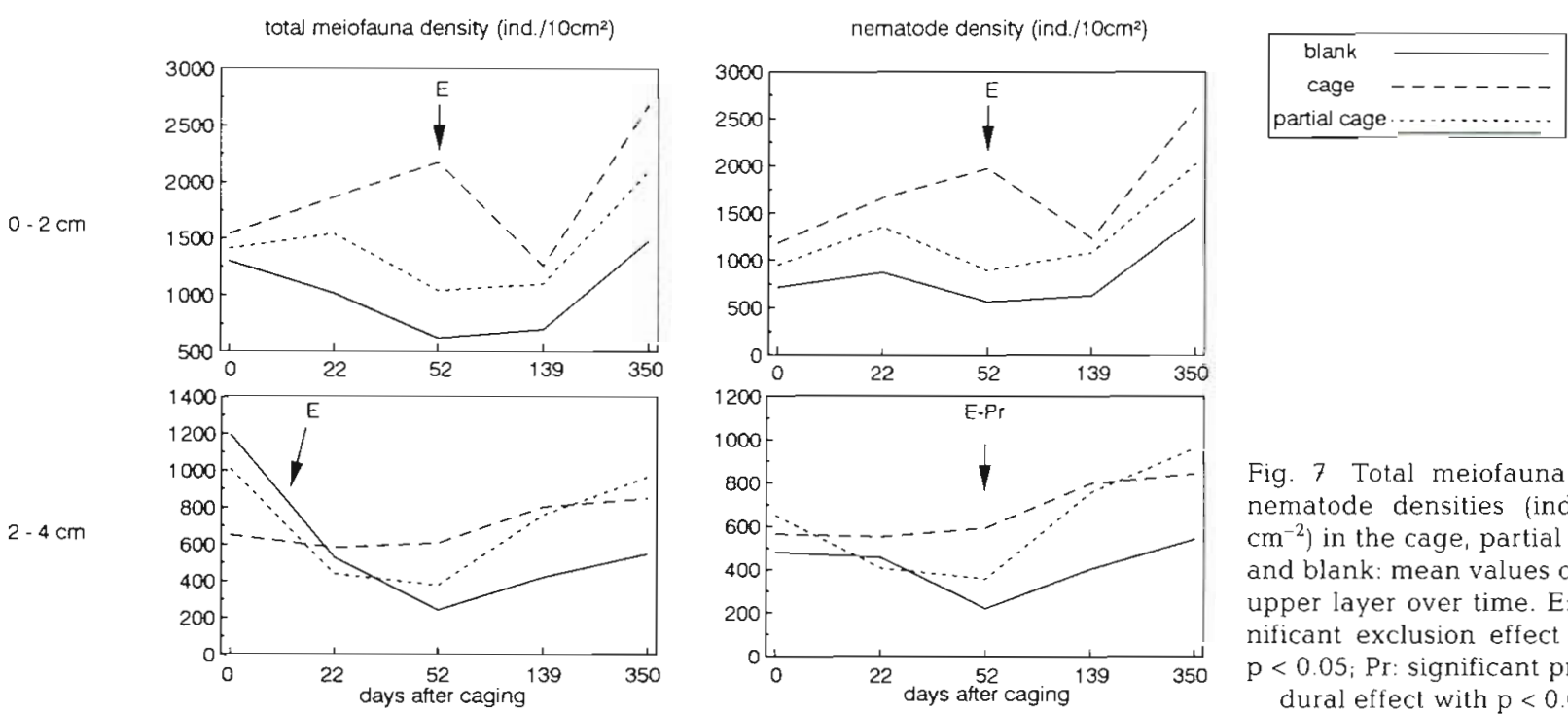

Fig. 7 Total meiofauna and nematode densities (ind. 10 $\mathrm{cm}^{-2}$ ) in the cage, partial cage and blank: mean values of the upper layer over time. E: significant exclusion effect with $\mathrm{p}<0.05$; Pr: significant procedural effect with $\mathrm{p}<0.05$

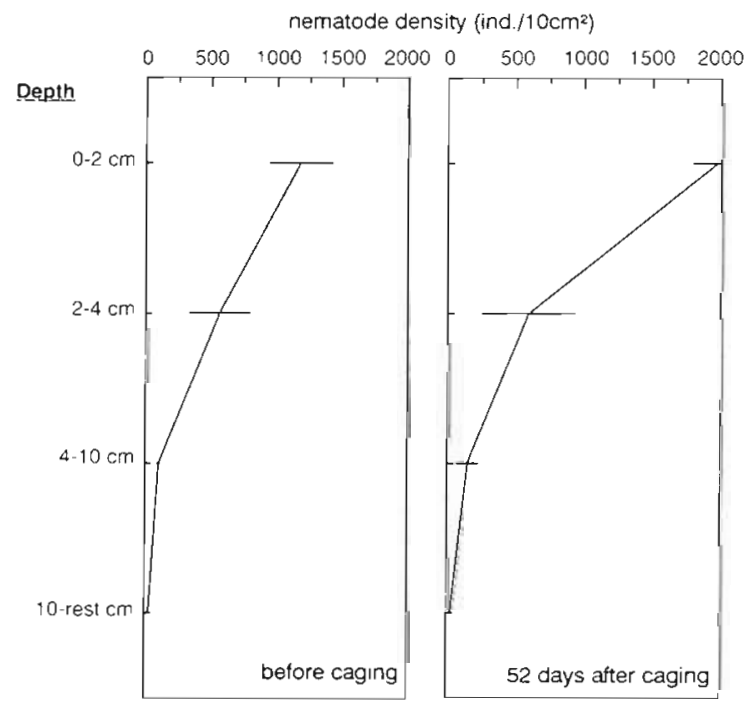

Fig. 8. Depth profile of the mean nematode density in the cage over 2 periods

Table 4. Mean density values (ind $10 \mathrm{~cm}^{-2}$ ) of the most common nematode genera of the surface and deepest layer in the cage over 2 periods

\begin{tabular}{|lcrrrr|}
\hline & $\begin{array}{c}\text { Feeding } \\
\text { type }\end{array}$ & \multicolumn{2}{c}{$\begin{array}{c}\text { Slice } \\
0-2 \mathrm{~cm}\end{array}$} & \multicolumn{2}{c|}{$\begin{array}{c}\text { Slice } \\
10-\text {-rest cm }\end{array}$} \\
& & Per 1 1 & Per. 3 & Per. 1 & Per. 3 \\
\hline Chromaspirina & 2B & 43.4 & 294.2 & 98.7 & 95.1 \\
Microlaimus & 2A & 43.5 & 185.5 & 246.7 & 268.8 \\
Daptonema & $1 \mathrm{~B}$ & 154.1 & 64.0 & 33.0 & 116.0 \\
Ptycholaimellus & 2A/2B & 158.1 & 179.1 & 32.9 & - \\
Sphaerolaimus & 2B & 71.1 & 95.9 & - & - \\
Spirinia & 2A & 71.1 & 121.5 & 16.4 & - \\
Desmodora & 2A & 142.3 & 179.1 & 82.3 & 54.5 \\
\hline
\end{tabular}

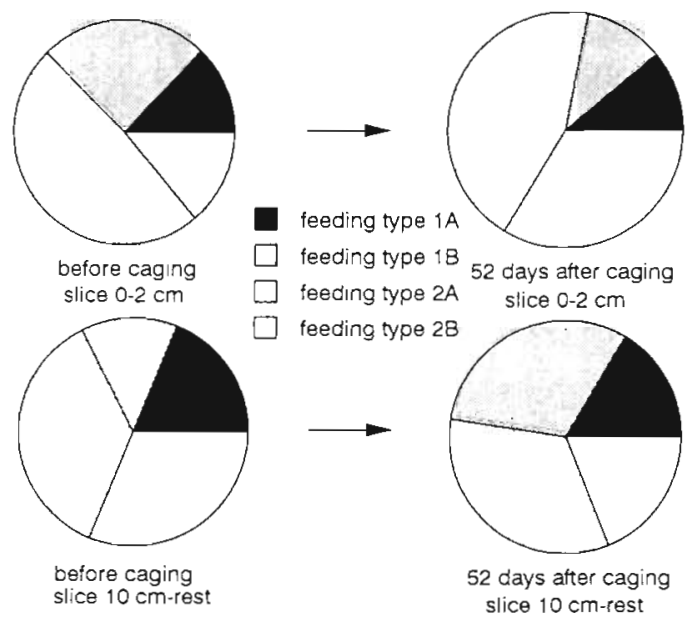

Fig. 9. Mean relative composition. $(\%)$ of the nematode feeding types (Wieser 1953) of the surface and deepest layer of the cage over 2 periods

decrease in the deeper layers (Fig. 8), which indicated that upward vertical migration could not explain the observations.

After 5 mo (period 4) and 1 yr (period 5) the exclusion effect was no longer detectable, density differences between treatments having fallen back to their original levels.

For nematode feeding guilds 2 parallel (though nonsignificant) trends were observed in the cages over time (Fig. 9). There was a general increase of feeding type $2 \mathrm{~B}$ (omnivores/predators) in slice $0-2 \mathrm{~cm}$ at the expense of type $1 \mathrm{~B}$ (non-selective deposit feeders) and there was no change for type $2 \mathrm{~A}$ (epistratum feeders). In the deepest layer an opposite change in feeding types occurred with a decrease in $2 \mathrm{~B}$ and an increase in $1 \mathrm{~B}$. 

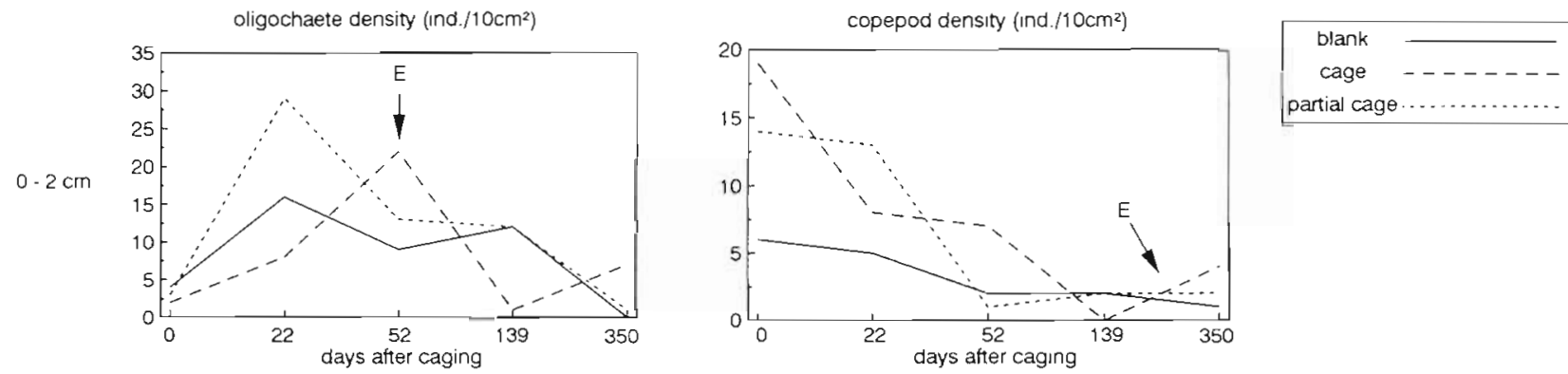

Fig. 10. Oligochaete and copepod densities (ind. $10 \mathrm{~cm}^{-2}$ ) in the cage, partial cage and blank: mean values of the upper layer over time. E: significant exclusion effect with $p<0.05$

As for the most common nematode genera, Chromaspirina and Sphaerolaimus (type 2B) and Ptycholaimellus and Spirinia (type 2A) increased conspicuously in the surface layer, whereas Daptonema (type 1B) increased in the deepest layer (Table 4)

As for the other meiofauna taxa, exclusion effects were demonstrated for copepod and oligochaete densities in the upper layer (Fig. 10, Table 5). The oligochaete response was observed as a density increase in the upper slice of the cage after 2 mo $(10 x)$. Copepod densities showed a general decline over 1 yr. ANOVA only showed a significant exclusion effect during the last half year of caging. The upward trend during this period was significantly stronger in cages $(4 \times)$ than in partial cages and blanks.

No effect. No procedural effect could be demonstrated for the patterns in nematode, oligochaete or copepod densities. Neither procedural nor exclusion effects could be detected for polychaetes, ostracods, halacaroids and kinorhynchs.

\section{DISCUSSION}

\section{Spatial distribution patterns}

The study shows a correlation of the meiobenthic community structure with physical gradients in the sediment. This may reflect a typical rigid system of abiotic factors regulating infaunal community structure in extreme eulittoral habitats (Hulings \& Gray 1976). Especially in mangrove sediments the pigment gradient is very conspicuous (Alongi 1989, Ming-Yi et
Table 5. Mean and standard deviation values of oligochaete and copepod density (ind $10 \mathrm{~cm}^{-2}$ ) of the surface layer in the 3 treatments ( $B, C$ and $P$ ) over 5 periods

\begin{tabular}{|lcrrrrr|}
\hline \multicolumn{6}{c}{ Treatment } & \multicolumn{5}{c|}{ Slice 0-2 cm } \\
& & Period 1 & Period 2 & Period 3 & Period 4 & Period 5 \\
\hline Oligochaeta & $\mathrm{B}$ & $4 \pm 1$ & $16 \pm 8$ & $9 \pm 6$ & $12 \pm 8$ & $0 \pm 0$ \\
& $\mathrm{C}$ & $2 \pm 3$ & $8 \pm 5$ & $22 \pm 1$ & $1 \pm 2$ & $7 \pm 4$ \\
& $\mathrm{P}$ & $3 \pm 2$ & $29 \pm 2$ & $13 \pm 8$ & $12 \pm 8$ & $1 \pm 1$ \\
Copepoda & $\mathrm{B}$ & $6 \pm 1$ & $5 \pm 3$ & $2 \pm 2$ & $2 \pm 2$ & $1 \pm 1$ \\
& $\mathrm{C}$ & $19 \pm 11$ & $8 \pm 5$ & $7 \pm 7$ & $0 \pm 0$ & $4 \pm 1$ \\
& $\mathrm{P}$ & $14 \pm 10$ & $13 \pm 9$ & $1 \pm 0$ & $2 \pm 2$ & $2 \pm 2$ \\
\hline
\end{tabular}

Table 6. Qualitative observations (-: absent; +: present; \pm : intermediate) of possible artefacts in the 3 treatments ( $B, C$ and $P$ ) after 1 and 5 mo of caging with procedurál evaluation

\begin{tabular}{|lcccccccc|}
\hline & \multicolumn{1}{c}{ After 1 mo of caging } & \multicolumn{1}{c|}{ After 5 mo of caging } & \multirow{2}{*}{ Evaluation } \\
& $\mathrm{B}$ & $\mathrm{C}$ & $\mathrm{P}$ & $\mathrm{B}$ & $\mathrm{C}$ & $\mathrm{P}$ & \\
\hline Fouling & - & - & - & - & - & - & OK \\
Shading & - & + & \pm & - & + & \pm & \pm Procedural \\
Sedimentation & - & - & - & - & - & - & OK \\
Moisture & - & - & - & - & + & + & Procedural \\
Litter fall & + & - & \pm & + & - & \pm & \pm OK \\
Epibenthos & + & - & + & + & - & + & \pm OK \\
\hline
\end{tabular}

al. 1994). Most meiofauna taxa have been shown to prefer subsurface $\mathrm{O}_{2}$ rich layers (Dye 1983a, Alongi \& Sasekumar 1992). It is therefore not surprising that they are found to be positively correlated to characteristics such as chlorophyll a concentration that are typical for these layers.

\section{Experimental design}

The meiofauna are useful subjects in cage exclusion experiments because of their short generation time and benthic larval stage (Bell 1980). Exclusion was achieved by removing large epibenthic organisms such 
as crabs and gastropods by hand. Besides the observed permanent epibenthos (which is dominant during low tide), the exclusion of the visiting epibenthos (hyperbenthos and demersal fishes) was also of importance.

The experimental procedure allowed us to study the overall effects of competition, predation and food enhancement by epibenthos. Since old biogenic structures (burrows) persisted throughout the experiment, the effects of physical modification and bioturbation prior to caging could not be assessed. Moreover, removal of epibenthos and sampling led to an artificial disturbance of the sediment.

Until now, most exclusion experiments have concentrated on interactions at the species level (Kneib 1988, Martin et al. 1989, Kneib 1991). However, Walters \& Moriarty (1993) advocated the use of amalgam species groups (e.g. higher taxa or functional groups), especially when the detailed species composition and trophic structure of the system are not known and when omnivory is important because of the absence of competitively dominant predators

Exclosure approaches have limitations (difficulty of selective exclusion and faster development of artefacts) compared to enclosures (Hall et al. 1990). However, possible artefacts (Hairston 1990) were taken into account by a detailed follow up in the field (Table 6) and by using a randomized block design with procedure controls (Hurlbert 1984)

The initial emplacement and burying of the lower cage wall in the sediment did not cause a major disturbance. It was gradually pushed down into man-made grooves between the roots without influencing the caged area.

\section{Experimental results}

\section{Abiotic factors}

Exclusion effect. Some sediment characteristics (\% of mud before combustion) and pigment concentration showed an exclusion effect in the upper layer. In general, there was an evolution in the cages to a muddier and pigment-richer sediment after $52 \mathrm{~d}$. The increase of the $\%$ of mud was due to detritus accumulation since the $\%$ of mud after combustion did not show a parallel increase. As the total organic material (\% of POM and C) in the sediment did not change, this detrital increase was most probably restricted to the muddy fraction of the detritus (Fig. 6).

Effects on the pigment concentration (chlorophyll a in particular) are correlated with changes in microalgae and diatoms (Gerdol \& Hughes 1994).

Procedural effect. It is obvious that the sediment of the treatments $\mathrm{P}$ and $\mathrm{C}$ became moister through time than that of treatment B as a result of the cage construction (Table 6). This resulted in lower temperatures and, later in the experiment, in lower salinities. Indeed, the exclusion effect on temperature could, in fact, be a procedural effect of the cage shadow which was less conspicuous in the partial cage (one side was open).

\section{Nematode and total meiofauna density}

An exclusion effect on nematode and total density was also reported by Dye \& Lasiak (1986) (an increase of $2 \times$ to even $5 \times)$, by Hoffman et al. (1984) (10x) and by Dittmann (1993) $(5 \times)$. Bell (1980) only found an exclusion effect for total meiofauna density.

Competition. The epibenthos in the Ceriops tagal vegetation was dominated by the crab Uca lactea annulipes ( 2 to 26 ind. $\mathrm{m}^{-2}$ ) and the gastropod Terebralia palustris ( 6 to 70 ind. $\mathrm{m}^{-2}$ ). According to Bell (1980) and Dye \& Lasiak (1986), competition with the nematodes is the driving force: the dominant epibenthos and pelagic fauna are thought to be important grazers on detritus and the associated bacteria, protozoans and fungi (Gerlach 1978, Alongi 1989). Stomach content analyses of Uca polita and Uca vocans and fiddler crabs in general revealed bacteria, microalgae and protozoans to be the dominant dietary items (Dye \& Lasiak 1986) The diet of gastropods in mangroves is limited to microalgae, bacteria and fungi (Branch \& Pringle 1987 in Alongi 1989). As in the present study, caging and exclusion of gastropods has been shown to cause an increase of chlorophyll $a$ in a study of Branch \& Branch (1980) (in Alongi 1989).

Consequently, the exclusion effect as a conspicuous increase of pigment concentration and muddy detritus could not have been entirely caused by the cage construction. Moreover, this exclusion effect was parallel to that on nematodes and total meiofauna (i.e. after $52 \mathrm{~d}$ of caging). Therefore, the nematodes and the epibenthos in this study are believed to compete for food.

Predation. With respect to the predation hypothesis, Uca pugnax and juvenile crabs in general have been shown to ingest nematodes (Bell 1980. Hoffman et al. 1984). Dittmann (1993) was convinced that consumption of, and predation on, the meiofauna by the dominant crab Mictyris longicarpus was the structuring factor

However, Dye \& Lasiak (1986) stressed that exclusion of predation as a driving force would lead to an upward vertical migration of nematodes. No evidence for this was found in our study, stressing the lack of predatory control (Alongi 1989)

Bioturbation. A third interaction possibility is disturbance due to bioturbation (Alongi 1989) caused by 
burrowing (Bright 1977, DePatra \& Levin 1989) or feeding activities or by the production of (pseudo)fecal pellets (Sherman \& Coull 1980, Hoffman et al. 1984, Dye \& Lasiak 1986, Dittmann 1993). As mentioned before, exclusion of bioturbation was probably not a driving force in our experiments.

Procedure. In this study, the effect of the cage construction itself was reflected in a decrease in the muddy fraction (after combustion), salinity and temperature in the cages and partial cages.

The potential effect of these changes is believed to be marginal as compared to the obvious exclusion effect on nematodes. Bell (1980) found no experimental effect on the muddy fraction, whereas Virnstein (1977) and Alongi (1989) found an increase due to water stagnation.

\section{Nematode genera composition}

Although the overall 2A type \% did not change, an increase of the most common type $2 \mathrm{~A}$ nematode genera (epistratal microalgae feeders) and an overall increase of type $2 \mathrm{~B}$ (omnivores/predators) in the upper layer was evident. It was followed by a new equilibrium in nematode density. Epistratum feeders were reacting to the microalgal abundance and could be rapidly grazed down by nematode predators that were partly coming from deeper layers. The presence of type $2 \mathrm{~B}$ could also be a reason for the decrease of type 1B nematodes, which were not or only slightly affected by competition. These findings support the competition hypothesis. Unfortunately, we did not compare these data with the evolution of feeding types in partial cage and blank treatments. A comparison would probably indicate possible significant exclusion and procedural effects on genus composition and trophic structure of the nematode community.

\section{Oligochaete density}

Hoffman et al. (1984) found a 4 -fold increase of annelids in general, while Dittmann (1993) showed a 5 -fold increase in oligochaetes.

Competition. From the 5 food categories for oligochaetes (Giere \& Pfannkuche 1982) the most important dietary item for interstitial tubificids and enchytraeids is believed to be organic matter enriched with bacteria rather than microalgae, which were found to be most important for nematodes (Giere 1975). Organic matter is particularly plentiful in littoral sands and muds. Indeed, it was this muddy detritus that showed a conspicuous exclusion effect in the experiment, indicating that the removal of epibenthos turned out to favour the oligochaetes in terms of competition for food.

Predation. Nevertheless, a decrease of predation by crabs (Dittmann 1993) or by juvenile fish can also be a possible factor. In temperate regions, there is evidence that young demersal fish (e.g. gobiids) prey upon oligochaetes (Giere \& Pfannkuche 1982). Virnstein (1977), on the other hand, showed with a cage experiment in a temperate shallow estuarine bottom that the dominant tubificid was largely unaffected by predation of crabs or fishes.

Bioturbation. It is known that the production of burrows and food and fecal pellets by crustaceans may have a positive effect on oligochaete numbers (Bell \& Coull 1978, Reise \& Ax 1979, Alongi \& Tietjen 1980 , Dittmann 1993). Indeed, the exclusion could possibly lead to a decrease in oligochaetes in the cages. However, this kind of effect was not observed in this experiment.

Procedure. As mentioned above, the 3 abiotic factors influenced by the cage construction were salinity (after $6 \mathrm{mo}$ ), and \% of mud (after combustion) and temperature (after $1 \mathrm{mo}$ ). The detailed composition of the oligochaete fauna is not known, which makes it difficult to analyse the response to changes in the abiotic environment.

\section{Copepod density}

Bell (1980), Hoffman et al. (1984) and Dittmann (1993) showed a similar exclusion effect on harpacticoid copepods.

Competition. With respect to competition regulation, only juvenile crabs were mentioned as possible competitors of copepods (Bell 1980). Their food is assumed to consist mainly of detritus, but selective grazing on single food particles has also been observed (Marcotte 1984 in Hicks \& Coull 1983).

Predation. Reise (1979) and Webb \& Parsons (1991) believed that predation has little or no influence. In contrast, Hoffman et al. (1984) and Dittmann (1993) proposed that it is mainly predation by epibenthos (such as crabs) that influences copepod numbers. The late effect in the present study (only in period 5) accords with the study of Bell (1980), who only found an effect on copepods after an exclusion lasting 9 mo. Hicks \& Coull (1983) thought that, especially for muddy or detrital substrata, juvenile fishes are primary predators on harpacticoids. These fishes were also excluded in our experiment. Hicks \& Coull (1983), Gee (1989) and Giere (1993) mentioned that, whereas nematodes and oligochaetes are certainly important in remineralization of organic matter and may be food items for epibenthic deposit-feeders, copepods seem to 
be the major taxon in terms of fish food and/or biomass transfer to the demersal-pelagic realm.

Bioturbation. It has been postulated that sediment reworking activities are an alternative structuring force (Bell \& Coull 1978, Reise 1979, Webb \& Parsons 1991, Olafsson \& Moore 1992). Our experiment did not show this kind of effect.

\section{Other taxa densities}

In contrast with our study, in which there was no effect on polychaetes, Bell (1980) and Hoffman et al. (1984) mentioned a significant increase.

The absence of an effect on polychaetes led to the question whether our experimental design was adequate to detect possible effects in the first place. Therefore, the techniques of power analysis (Cohen 1977) were employed for a post hoc determination of the sensitivity of our experiment. The parameters significance level (0.05), effect size ( 0.274 calculated from ANOVA variances) and sample size (3) permitted us to estimate a power level of $11 \%$ via power tables provided by Cohen (1977). Such a low power value was also common in subtidal caging experiments, and it limits the detection power of effects on polychaetes severely (Hall et al. 1990).

The same can be concluded for effects on ostracod $(18 \%)$, halacaroid $(32 \%)$ and kinorhynch $(13 \%)$ numbers.

\section{CONCLUSION}

Exclusion of all epibenthos from a Ceriops tagal mangrove sediment clearly influenced the nematode, oligochaete and copepod densities, i.e. the dominant part of the total meiobenthos. The excluded permanent epibenthos was dominated by detritivores. Besides a possible sheltering effect, the absence of epibenthos in particular led to an increase in muddy detritus and microalgae in the surface layer. This was followed by a higher abundance of diatom-feeding nematodes (type $2 \mathrm{~A}$ ) and oligochaetes and a subsequent increase in predatory nematodes (type $2 \mathrm{~B}$ ). Eventually, it brought the system to a new equilibrium.

The structure of the meiofauna community is regulated not only by the physical environment, but mainly by biological, competitive interactions with the epibenthos. These findings indicate that the meiofauna community of mangrove sediments is part of an isolated, detrital food web with only minor predator-prey interactions with the epibenthos. The impact of epibenthos on meiofauna is further complicated by multilevel interactions with other infaunal macrobenthos. A publication on this effect is in preparation.
Acknowledgements. This research was financed by the FKFO-programme 32.0043 .88 and 32.0009 .92 of the Belgian National Fund for Scientific Research in cooperation with the EC project 'Dynamics and Assessment of the Mangrove Ecosystem in Kenya' Dr E. Okemwa (K.M.F.R.I., Mombasa, Kenya), Prof. Dr A. Coomans (Institute of Zoology, University of Gent) and the Kenya Belgium Project in Marine Sciences are acknowledged for the optimal research facilities that were provided. Jan Mees and Sandra Vanhove gave helpful comments. The help of the technical staff of the Institute of Zoology was indispensable in the sampling and sample processing. The first author acknowledges a grant from the Belgian National Fund for Scientific Research (N.F.W.O.)

\section{LITERATURE CITED}

Alkemade R, Wielemaker A, Hemminga MA (1993) Correlation between nematode abundance and decomposition rate of Spartina anglica leaves. Mar Ecol Prog Ser 99: $293-300$

Alongi DM (1989) The role of soft-bottom benthic communities in tropical mangrove and coral reef ecosystems. Rev aquat Sci 1:243-280

Alongi DM, Christoffersen P (1992) Benthic infauna and organism-sediment relations in a shallow, tropical coastal area: influence of outwelled mangrove detritus and physical disturbance. Mar Ecol Prog Ser 81:229-245

Alongi DM, Sasekumar A (1992) Benthic communities, Chap 6. In: Robertson AI, Alongi DM (eds) Tropical mangrove ecosystems. American Geophysical Union, Washington, DC, p $137-227$

Alongi DM, Tietjen JH (1980) Population growth and trophic interactions among free-living marine nematodes. In: Tenore KR, Coull BC (eds) Marine benthic dynamics. University of South Carolina Press, Columbia, p 151-166

Bell SS (1980) Meiofauna-macrofauna interactions in a high salt marsh habitat. Ecol Monogr 50:487-505

Bell SS, Coull BC (1978) Field evidence that shrimp predation regulates meiofauna. Oecologia 35:141-148

Bright DB (1977) Burrowing Central American mangrove land crabs and their burrow associates. Mar Res Indonesia $18: 87-99$

Castel $\mathbf{J}$ (1992) The meiofauna of coastal lagoon ecosystems and their importance in the food web. Vie Milieu 42: $125-135$

Cohen J (1977) Statistical power analysis for the behavioural sciences. Academic Press, New York

Connell JH (1983) On the prevalence and relative importance of interspecific competition: evidence from field experiments. Am Nat 122:661-695

DePatra KD, Levin LA (1989) Evidence of the passive deposition of meiofauna into fiddler crab burrows. J exp mar Biol Ecol 125:173-192

Dittmann S (1993) Impact of foraging soldiercrabs (Decapoda: Mictyndae) on meiofauna in a tropical tidal flat. Rev Biol Trop 41(3):627-637

Dye AH (1983a) Vertıcal and horizontal distnbution of meiofauna in mangrove sediments in Transkei, Southern Africa. Estuar coast Shelf Sci 16:591-598

Dye $\mathrm{AH}$ (1983b) Composition and seasonal fluctuations of meiofauna in a Southern Africa mangrove estuary. Mar Biol 73:165-170

Dye AH, Furstenberg JP (1.978) An ecophysiological study of the meiofauna of the Swartkops estuary. II. The meiofauna: composition, distribution, seasonal fluctuation and bromass. Zool Afr 13:19-32 
Dye AH, Lasiak TA (1986) Microbenthos, meiobenthos and fiddler crabs: trophic interactions in a tropical mangrove sediment. Mar Ecol Prog Ser 32:259-264

Gee JM (1989) An ecological and economic review of meiofauna as food for fish. Zool J Linn Soc 93:243-261

Gee JM, Warwick RM, Davey JT, George CL (1985) Field experiments on the role of epibenthic predators in determining prey densities in an estuarine mudflat. Estuar coast Shelf Sci 21:429-448

Gerdol V, Hughes RG (1994) Effect of Corophium volutator on the abundance of benthic diatoms, bacteria and sediment stability in two estuaries of southeastern England. Mar Ecol Prog Ser 114:109-115

Gerlach SA (1978) Food-chain relationships in subtidal silty and marine sediments and the role of meiofauna in stimulating bacterial productivity. Oecologia 33:55-69

Giere O (1975) Population structure, food relations and ecological role of marine oligochaetes. With special reference to meiobenthic species. Mar Biol 31:139-156

Giere O (1993) Meiobenthology - the microscopic fauna in aquatic sediments. Springer-Verlag, New York

Giere O, Pfannkuche $O$ (1982) Biology and ecology of marine Oligochaeta, a review. Oceanogr mar Biol A Rev 20:173-308

Hairston NG (1990) Ecological experiments - purpose, design and execution. Cambridge University Press, Cambridge

Hall SJ, Raffaelli D, Robertson MR, Basford DJ (1990) The role of the predatory crab, Liocarcinus depurator, in a marine food web. J Anim Ecol 59:421-438

Heip C (1980) The influence of competition and predation on production of meiobenthic copepods. In: Tenore KR, Coull $\mathrm{BC}$ (eds) Marine benthic dynamics. University of South. Carolina Press, Columbia, p 167-177

Hicks GRF, Coull BC (1983) The ecology of marine meiobenthic harpacticoid copepods. Oceanogr mar Biol A Rev 21:67-175

Hoffman JA, Katz J, Bertness MD (1984) Fiddler crab depositfeeding and meiofaunal abundance in salt marsh habitats $\mathrm{J}$ exp mar Biol Ecol 82:161-174

Hulings NC, Gray JS (1976) Physical factors controlling abundance of meiofauna on tidal and atidal beaches. Mar Biol $34: 77-83$

Hurlbert SH (1984) Pseudoreplication and the design of ecological field experiments. Ecol Monogr 54:187-211

Kneib RT (1988) Testing for indirect effects of predation in an intertidal soft-bottom community. Ecology 69:1795-1805

Kneib RT (1991) Indirect effects in experimental studies in marine soft-sediment communities. Am Zool 31:874-885

Kokwaro Jo (1986) The distribution and economic importance of the mangrove forests of Kenya. J E Afr nat Hist Soc nat Mus 75:1-12

Mantoura RFC, Llewellyn CA (1983) The rapid determination of algal chlorophyll and carotenoid pigments and their breakdown products in natural waters by reverse-phase high-performance liquid chromatography. Analytica Chim Acta 151:297-314

Marinelli RI, Coull BC (1987) Structural complexity and juvenile fish predation on meiobenthos: an experimental approach. J exp mar Biol Ecol 108:67-81

Martin TH, Wright RA, Crowder LB (1989) Non-additive impact of blue crabs and spot on their prey assemblages. Ecology 70:1935-1942
McLachlan A, Romer G (1990) Trophic relations in a high energy beach and surf-zone ecosystem. In: Barnes $M$, Gibson RN (eds) Trophic relations in the marine environment. Proc 24 th Eur mar biol Symp. Aberdeen University Press, Aberdeen, p 356-371

Ming-Yi S, Aller RC, Lee C (1994) Spatial and temporal distributions of sedimentary chloropigments as indicators of benthic processes in Long Island Sound. J mar Res 52: $149-176$

Olafsson E, Moore CG (1992) Effects of macroeplfauna on developing nematode and harpacticoid assemblages in a subtidal muddy habitat. Mar Ecol Prog Ser 84:161-171

Reise K (1979) Moderate predation on meiofauna by the macrobenthos of the Wadden Sea. Helgoländer wiss Meeresunters 32:453-465

Reise K, Ax P (1979) A meiofaunal 'thiobios' limited to the anaerobic sulfide system of marine sand does not exist. Mar Biol 54:225-237

Ruwa RK, Polk P (1986) Additional information on mangrove distribution in Kenya: some observations and remarks. Kenyan J Sci (Ser B) 7:41-45

Schrijvers $J$ (in press) Meiobenthos of Ceriops and Rhizophora mangroves at Gazi Bay, Kenya: human impact. Academia Analectae (Meded K Acad Wet Lett Schone Kunsten Belg Kl Wet)

Schrijvers J, Van Gansbeke D, Vincx M (1995) Macrobenthic infauna of mangroves and surrounding beaches at Gazi Bay, Kenya. Hydrobiologia 306:53-66

Sherman KM, Coull BC (1980) The response of meiofauna to sediment disturbance. J exp mar Biol Ecol 46:59-71

Sultan Ali MA, Krishnamurthy $K$, Prince Jeyaseelan MJ (1983) Energy flow through the benthic ecosystem of the mangroves with special reference to nematodes. Mahasagar Bull nat Inst Oceanogr 16:317-325

Tenore KR, Rice DL (1980) A review of trophic factors affecting secondary production of deposit-feeders. In: Tenore $\mathrm{KR}$, Coull BC (eds) Marine benthic dynamics. University of South Carolina Press, Columbia, p 325-340

Tietjen JH, Alongi DM (1990) Population growth and effects of nematodes on nutrient regeneration and bacteria associated with detritus from northeastern Queensland (Australia). Mar Ecol Prog Ser 68:169-179

Vanhove S (1993) Size spectra of nematode assemblages in an East African mangrove. Academia Analectae (Meded K Acad Wet Lett Schone Kunsten Belg KI Wet) 55:127-142

Vanhove S, Vincx M, Van Gansbeke D Gijselinck W, Schram D (1992) The meiobenthos of five mangrove vegetation types in Gazi Bay, Kenya. Hydrobiologia 147:99-108

Virnstein RW (1977) The importance of predation by crabs and fishes on benthic infauna in Chesapeake Bay. Ecology 58:1199-1217

Walters K, Moriarty DJW (1993) The effects of complex trophic interactions on a marine microbenthic community. Ecology 74:1475-1489

Webb DG, Parsons TR (1991) Impact of predation-disturbance by large epifauna on sediment-dwelling harpacticoid copepods: field experiments in a subtidal seagrass bed. Mar Biol 109:485--491

Wieser, von W (1953) Die Beziehung zwischen Mundhöhlengestalt, Ernährungsweise und Vorkommen bei freilebenden marinen Nematoden. Eine ökologischmorphologische Studie. Ark Zool 4:439-484

Manuscript first received: December 12, 1994

Revised version accepted: May 26, 1995 